\title{
ONDJAKI E SUA YNARI: IMAGENS DA CRIANÇA E DA INFÂNCIA
}

Márcia Manir Miguel Feitosa (UFMA)

Vanessa Soeiro Carneiro (UFMA)

Fiquei um bocado a pensar, as palavras, as palavras que uma pessoa às vezes diz a outra pessoa, às vezes são palavras que uma pessoa diz sem pensar, sobretudo quando estamos a discutir, saem só assim, outras vezes são palavras que a pessoa andou muito tempo a preparar porque quer dizer uma coisa ao outro e só se diz com palavras bem preparadas, e nem sempre é bom preparar muito as palavras, às vezes falar à toa ou rápido faz sair palavras com mais verdade e força de convencer o outro.

(ONDJAKI - A AvóDezanove e o segredo do soviético)

Revelação. Porque tem horas assim na vida da pessoa: uma palavra só, inocente, muda o tudo no mundo.

(VIEIRA, Macandumba)

Resumo: O escritor angolano Ondjaki é um dos principais autores contemporâneos da Literatura Africana de língua portuguesa. Entre suas diversas obras, está o livro infantil Ynari: a menina das cinco tranças que retrata a jornada da menina Ynari junto com seu amigo, o homem pequenino, em busca de compreender os sentidos de algumas palavras. O objetivo desse artigo é, através de uma pesquisa bibliográfica e qualitativa, analisar como a criança e a infância são representadas em Ynari: a menina das cinco tranças.

Palavras-chave: Literatura Angolana; Infância; Ondjaki.

Abstract: The Angolan writer Ondjaki is one of the leading contemporary writers of African Literature of Portuguese language. Among his many works is the childish book Ynari: a menina das cinco tranças, which depicts the journey of the girl Ynari along with her friend, the little man, seeking to understand the meanings of some words. The aim of this article is analyze how the child and childhood are represented in Ynari: a menina das cinco tranças through a bibliographic and qualitative research.

Keywords: Angolan Literature; Childhood; Ondjaki. 


\section{INTRODUÇÃO}

Ndalu de Almeida nasceu em Luanda, capital de Angola, em 1977, e começou a escrever ainda criança. Atualmente, Ondjaki, nome sob o qual atende enquanto escritor, possui mais de uma dezena de livros publicados, sendo muitos deles premiados em diferentes países. Isso contribui para que possa ser visto como um dos principais autores contemporâneos da Literatura Africana de Língua Portuguesa. Ynari: a menina das cinco tranças, originalmente publicado em 2004, é uma de suas obras infantis.

A escrita de Ondjaki nesse livro reflete o ponto de vista infantil sobre discórdias típicas do mundo adulto ao retratar a jornada da menina Ynari junto com seu amigo, o homem pequenino. Ao partir em uma aventura para construir e destruir palavras, a criança aprende o verdadeiro sentido de algumas delas, como "amizade" e "paz".

O objetivo desse artigo é analisar como a criança e a infância são representadas em Ynari: a menina das cinco tranças, valorizando, assim, não somente a figura infantil e a literatura angolana, mas, principalmente, a criança africana. É importante ressaltar que, devido à carência de estudos africanos que dissertem sobre a infância, não encontramos suporte para este artigo e, por essa razão, os conceitos utilizados neste trabalho seguem um viés eurocêntrico. 


\section{A LITERATURA AFRICANA DE LÍNGUA PORTUGUESA}

A história da Literatura Africana de Língua Portuguesa está diretamente relacionada à colonização dos países africanos lusófonos. No entanto, precisamos ter o cuidado de não pensar nessa literatura a partir do olhar da ex-metrópole, porque "estudar a África pelo prisma do ex-colonizador é um crime intelectual" (MATA, 2009, p.6). Ou seja, ao estudarmos a Literatura Africana de Língua Portuguesa precisamos considerá-la a partir do ponto de vista dos próprios países africanos, e não de Portugal.

Sabemos que essa literatura surgiu através de um longo processo histórico que se iniciou por volta das décadas de 40 e 50 do século XIX e que envolve tanto a assimilação da língua do colonizador quanto à autoconscientização do colonizado e de sua cultura. De acordo com Maria Nazareth Fonseca e Terezinha Moreira (2007), a Literatura Africana Lusófona passa por, pelo menos, quatro fases distintas.

A primeira fase é a da assimilação, quando os escritores ainda estão "alienados" no que diz respeito à sua própria cultura e por isso buscam imitar a escrita europeia. Seus textos são marcados pela herança advinda dos movimentos literários europeus e americanos e não possuem características próprias que os identifiquem 
como africanos e os diferenciem dos textos produzidos em outros continentes.

A segunda é a da resistência e nela ocorre o rompimento com o padrão europeu, revelando a influência do meio através de sua escrita e mostrando os primeiros sinais de um sentimento nacionalista. A terceira ocorre depois da independência e mostra o escritor africano tentando se afirmar como tal. Segundo Fonseca e Moreira (2007), esse é o momento de "desalienação" da escrita, no qual o autor adquire a consciência de colonizado e passa a produzir um discurso de revolta.

A quarta e última fase é a independência e a consolidação do trabalho do autor africano lusófono, é o momento da produção de textos em liberdade. Nessa etapa, que corresponde à contemporaneidade, são delineados os novos rumos dos movimentos literários africanos, de acordo com as particularidades culturais de cada país, ao mesmo tempo em que os escritores buscam fazer com que a Literatura Africana de Língua Portuguesa ocupe lugar dentro do cânone literário universal.

É importante ressaltarmos que essas fases não são inflexíveis e rigidamente delimitadas, ou seja, elas podem ser intercambiáveis. Obras produzidas por um mesmo 
escritor africano podem atravessar mais de uma dessas fases, carregando consigo tanto valores apreendidos do colonizador quanto valores próprios da literatura e da cultura africanas.

\section{A LITERATURA ANGOLANA}

Em Angola, segundo Tânia Macedo (2009), a literatura nacional só se consolidou no final dos anos 1940 graças ao Movimento dos Novos Intelectuais de Angola que propunham redescobrir o país e modernizar a cultura. Para tanto eles buscaram romper com a cultura tradicional imposta pelo colonialismo e se inspirar na cultura angolana e na história do seu povo, intensificando, assim, a relação entre literatura e sociedade.

A produção poética em Angola "abrange três grandes períodos: de 1950 a 1970, marcado pela conscientização; a década de 1970, marcada pelas inovações estéticas; e a geração de 1980" (FONSECA e MOREIRA, 2010, p.17). O primeiro período foi a fase da conscientização da problemática angolana, do homem negro, de sua cultura, dos valores ancestrais da população africana e da busca por uma identidade nacional própria. A literatura produzida nesse período consagrou-se fortemente anticolonialista. 
Ainda segundo Fonseca e Moreira, durante a segunda fase, os escritores buscaram maior rigor literário e a vinculação à temática política, mas sem produzir uma literatura panfletária. Já a principal característica da literatura produzida durante o terceiro período foi o ecletismo.

Quanto à Literatura Angolana contemporânea, é póscolonialista e busca revelar uma identidade própria e se reafirmar enquanto país. Essa reafirmação se dá por diferentes maneiras, sendo uma delas a oraturização da língua portuguesa, um processo que

[...] ultrapassa o código linguístico e se expande por terrenos translinguísticos como a onomasiologia (a onomástica e a toponímia, sobretudo), a cenarização (o registo das vozes, a rítmica da dicção e a representação dos gestos) e a sugestão musical. Todos esses recursos de narração rubricam-lhe uma forma mimética e permitem identificar, na fala narrativa, a interacção entre a escrita e os textos não escritos incorporados na cultura local, que se dão a conhecer em português. (MATA, 2000, p.4)

A oraturização é a maneira como os autores estruturam o português em seus textos, africanizando-os e trabalhandoos em conjunto com expressões típicas de idiomas africanos.

Ainda, segundo Mata (2000), outro modo pelo qual isso acontece é através de um processo de remitologização 
da literatura, isto é, da busca por reforçar a cultura e as crenças africanas. Esse reforço ocorre muitas vezes a partir do uso do absurdo e do insólito na literatura como forma de enfrentamento do real. Para a pesquisadora, "o insólito surge como a lógica possível e uma realidade que, de tão absurda, carece de explicação a partir do real. Através de construções simbólicas, alegóricas e insólitas, intentase recuperar o sentido da realidade". (MATA, 2000, p.6). Pensando essa literatura a partir da própria cultura africana, compreendemos que o insólito é produzido por meio do realismo animista.

\section{AS CONCEPÇÕES DE CRIANÇA E DE INFÂNCIA NO DECORRER DA HISTÓRIA}

Na Idade Antiga, as pessoas não passavam pela fase da infância simplesmente porque essa etapa da vida como a compreendemos atualmente - não existia nas sociedades vigentes na época. Quando uma pessoa deixava de ser um bebê e ganhava alguma "independência", já era automaticamente inserida no mundo dos adultos. As crianças se vestiam e trabalhavam assim como os adultos e frequentavam os mesmos ambientes.

Elas não recebiam tratamento especial algum e, segundo a pesquisadora Fernanda Coutinho (2012), eram, muitas vezes, 
comparadas com animais que, mesmo sendo capazes de praticar ações voluntárias, não possuíam, para Aristóteles, a habilidade de fazer escolhas. Para ela, "ao tentar superpor a imagem da criança e do adulto, o pensamento do filósofo grego finda por superestimar esse último em relação à primeira, impedindo como tal, a expressão dos traços diferenciais das idades". (COUTINHO, 2012, p.26). Ou seja, Aristóteles considerava as crianças incapazes e inferiores e esse não era um pensamento particular do filósofo, mas sim uma ideia predominante na Grécia antiga. Vistas muitas vezes como um estorvo para os pais, as crianças eram desprezadas até que atingissem a maturidade. Entretanto,

a visão negativa da criança foi deixada de lado, em algumas situações, como no caso da compreensão dos estóicos, que exaltaram a bondade natural da criança, opinião assimilada, posteriormente, pelo pensamento romano, através de Cícero e mesmo de Sêneca. Cícero, por exemplo, alertava para a importância da observação das diversas etapas da apreensão do mundo pelo infante, índices que poderiam ser buscados com esta ainda no berço. (COUTINHO, 2012, p.27)

Para os romanos, a criança também poderia ser vista como símbolo de pureza e inocência e como uma promessa de ternura. Apesar disso, continuava sendo desvalorizada 
na maior parte do tempo. Os índices de abandono de bebês entre os latinos eram altos, e isso acontecia ora devido a questões financeiras, ora por motivos banais, a exemplo do desinteresse pelo sexo da criança.

Já na Idade Média, muitos filósofos contribuíram para a permanência desse desapreço em relação à figura infantil, tão comum na Idade Antiga. Para Santo Agostinho, por exemplo, o infante deveria ser desassociado da noção de inocência, enquanto para São Bernardo o choro do bebê, ao nascer, estava relacionado ao pecado. Quanto mais alto e intenso era o choro, maior era o pecado carregado pela criança e a sua necessidade de batismo (COUTINHO, 2012).

Por outro lado, a figura do menino Jesus passou a ser cultuada com mais frequência, possibilitando, assim, às vésperas da Renascença, "uma apreciação menos severa da infância e, por este tempo, até mesmo uma aura mítica, de inspiração sapiencial, Ihe é conferida". (COUTINHO, 2012, p.29). Isso faz com que os estereótipos da criança divina (angelical, humilde, paciente, etc) se misture ao da criança comum. Dessa forma, o infante passa a ser visto de maneira paradoxal tanto como símbolo de imperfeição quanto de pureza e inocência. Segundo Coutinho (2012), essa ambiguidade fez com que a realidade infantil começasse 
a ser percebida como um quebra-cabeça que desafiava a compreensão dos adultos. Desse modo, a visão negativa sobre a criança deixou de ser predominante e passou a dividir espaço com uma visão um pouco mais apreciativa no final da Idade Média.

A ideia de infância e a preocupação pedagógica são pensamentos modernos que começaram a surgir e a se desenvolver na Idade Moderna, entre os séculos XVI e XVII, quando os costumes da sociedade começaram a mudar, costumes esses que estavam ligados principalmente à maneira de se vestir, separação de crianças por classe social, família e preocupação com a educação e com os comportamentos infantis. Todas essas mudanças ocorreram devido à alteração do modelo de civilidade da época que ditava o que era ter boas maneiras e seguir as regras de etiqueta.

No entanto, ainda não existia vínculo familiar entre pais e filhos. Segundo os pesquisadores Paula de Sá e Diógenes Carvalho (2014), as famílias burguesas costumavam entregar as crianças aos cuidados de amas-de-leite logo após o nascimento e, depois que cresciam, eram enviadas para estudar em conventos, longe de casa. Isso eximia os pais da criação dos seus filhos e impedia que um laço afetivo real se estabelecesse no seio das famílias. Ainda conforme 
Sá e Carvalho (2014), outro fator que contribuía para que isso ocorresse era o alto índice de mortalidade infantil que fazia com que as mulheres tivessem que dar à luz diversas vezes, na esperança de que, pelo menos, alguns de seus filhos sobrevivessem. Compreendemos então que o distanciamento que os pais mantinham dos filhos era também uma espécie de mecanismo de autopreservação emocional: quanto menos ligados fossem às suas crianças, menos sofreriam se elas morressem.

No século XVIII, quando o ensino começa a ser dividido por faixas etárias, a ideia de infância se firma. A partir daí e com o passar do tempo, começam a ser criadas políticas sobre o trabalho infantil e sobre os direitos da criança. É importante destacar que o desenvolvimento da concepção de criança e de infância está fortemente ligado ao desenvolvimento da educação e das práticas pedagógicas. (BARBOSA; MAGALHÃES, 2008).

A criança passa, então, a ser não só apreciada pela sociedade, mas também valorizada, e um dos motivos pelos quais isso ocorre é a autovalorização, estabelecida pelo Renascimento, do indivíduo pela burguesia. Destarte, o homem começa a valorizar os frutos que nasciam de si mesmo e a dar mais importância a seus filhos. É nesse contexto que 
nasce a família nuclear, espaço de aconchego no qual "a criança passa a despertar nos pais uma afetividade particular oriunda de sua própria personalidade". (COUTINHO, 2012, p.31). Devido a essa intimidade, até então inexistente, entre pais e filhos, a família passa a dividir a responsabilidade com a escola pela formação das crianças.

É interessante destacar que essa concepção de infância foi, inicialmente, aplicada somente às classes altas. Os pais que possuíam melhor segurança financeira tinham condições de propiciar a seus filhos a educação e a oportunidade de viverem o período da infância. Mas os filhos, cujos pais não possuíam tal estabilidade financeira, foram forçados a trabalhar para auxiliar no sustento da família. Por isso, tais crianças não tinham a oportunidade de "serem crianças". Com o passar do tempo é que essa concepção de criança passou a ser aplicada também às classes sociais mais baixas.

A partir desse período, começam a ser desenvolvidas literaturas voltadas para as crianças ou aquelas que, no enredo, as tenham como foco. Além disso, começa a ser difundido o mito do infante como um ser pueril e da infância como sendo a "idade de ouro". Essa valorização da criança e da infância desperta o interesse de pesquisadores de diferentes áreas (como Freud, na Psicologia, e Vigostky, na 
Pedagogia) que passam a eleger a criança enquanto objeto de estudo. Com base em todas as teorias aqui apresentadas, analisaremos como a infância e a criança são retratadas na obra Ynari: a menina das cinco tranças.

\section{A CRIANÇA E A INFÂNCIA EM YNARI: A MENINA DAS CINCO TRANÇAS}

As figurações de criança e de infância em Ynari: $a$ menina das cinco tranças são extremamente simbólicas e se apresentam sob vários enfoques. Para os pesquisadores Jean Chevalier e Alain Gheerbrant (2012), a infância simboliza a inocência, sendo o estado anterior ao pecado e, portanto, o estado edênico. Esse simbolismo é reforçado pelos estudos de Coutinho e sua análise do quadro $A$ vida da humanidade:

É sabido que as representações sobre as idades da vida abarcam vários troncos míticos, possibilitando, inclusive, a mescla de tradições sagradas e profanas, nas criações artísticas. É o que acontece em $A$ Vida da Humanidade, quadro de Gustave Moreau. [...] Esta narrativa pictural, de tríplice geometria, relata os percursos existenciais de Adão, Orfeu e Caim, figuras consideradas pelo pintor como exemplares das etapas da vida há pouco aludidas. No retábulo, Adão traz em si a simbologia do princípio, da infância da humanidade, pela expressão das qualidades inaugurais da vida, que seriam, segundo o artista: "ingenuidade, candura, pureza". (2012, p.24) 
A noção de infância como um período edênico e a de criança como uma espécie de Adão estão intrinsecamente conectadas e se complementam. Ambas são extremamente perceptíveis na obra porque, assim como Adão, quando vivia no Éden, Ynari é uma criança inocente, ingênua e pura, a representar a criança curiosa ainda em fase de aprendizagem do mundo ao redor, que não hesita em questionar e em se surpreender com as descobertas feitas.

Ela ainda desconhece o significado de diversas palavras e se deslumbra quando aprende seus sentidos e o fato de que elas podem ser usadas em diferentes situações, como podemos observar no seguinte trecho:

- E a palavra "explosão"?

- Eu acho que a palavra "explosão" só devia ser usada noutras situações, não em situações de guerra.

- Em que situações? - perguntou Ynari, enquanto olhava para o rio, porque os peixes já saltavam, já tinham acordado.

- Queres pensar comigo? - disse o homem pequeno e mágico.

- Começa tu - pediu Ynari.

- Então, eu acho que a palavra "explosão" podia ser mais utilizada entre as estrelas. Quando elas se chocam, nós aqui no 
planeta Terra vemos uma coisa linda acontecer no céu...

- Ah! Que bonito - exclamou Ynari - E uma "explosão de alegria", pode ser?

- Claro! - Riu bem alto o homem pequeno e mágico.

- E uma "explosão de cores"?

- Também... Também pode ser. (ONDJAKI, 2010, p.28)

Outro fato que podemos perceber nesse trecho é que as perguntas de Ynari não são desprezadas pelos adultos. Pelo contrário, eles a incentivam a desenvolver questionamentos e estimulam a sua curiosidade. Tanto o homem pequenino quanto a velha muito velha, o velho muito velho e a avó da menina se importam com suas dúvidas e com o que ela sente. Quando Ynari chega à aldeia depois de conhecer o homem pequenino e vai dormir, sua avó a procura para saber se está triste: "- Estás tristes por causa dos olongos? - a avó perguntou." (ONDJAKI, 2010, p.11). A preocupação com os sentimentos da menina revela a valorização dos sentimentos das crianças como um todo.

A comunidade retratada na obra se importa com o que as crianças têm a dizer e valoriza suas opiniões. Isso é perceptível em um outro momento da narrativa quando Ynari chega à 
aldeia dos surdos e pede para falar com o soba (o chefe da aldeia). O chefe não hesita em conversar com a menina e não a trata em momento algum como alguém inferior a ele:

- Já entendi, mas diz-me uma coisa...

- O que é? - perguntou o mais velho.

- Se eu vos ensinar a ouvir os passarinhos, vocês deixam de estar em guerra?

- Sim. Nós só queremos saber usar a palavra "ouvir".

- Muito bem. Então peço-te que juntes todo o teu povo hoje de noite, faças uma fogueira, arranjes uma cabaça. E eu vou ensinar-vos a palavra "ouvir".

Assim foi. (ONDJAKI, 2010, p.29-30)

Ele não apenas ouve com atenção o que Ynari diz, mas também faz o que ela pede, revelando que, em Ynari: a menina das cinco tranças, as crianças são tratadas com igualdade pelos adultos que acreditam que elas sejam inteligentes e capazes de tomar decisões e resolver problemas.

Além disso, o modo como Ynari encara o mundo sugere que ela não cria dificuldades e obstáculos para as suas ações e age espontaneamente. Ao encontrar um desconhecido à beira do rio, faz amizade com ele; se tem uma dúvida, ela pergunta; se há aldeias em guerra, ela conversa e busca encontrar uma 
solução para o conflito. Percebemos então que as crianças têm visão simplificada de como as coisas são e é por isso que, segundo Chevalier e Gheerbrant (2012), elas também simbolizam a simplicidade natural e a espontaneidade.

Retomando a ideia de infância como um período edênico, a maneira como a menina interage com a natureza lembra muito a forma como Adão vivia no jardim do Éden:

Ela gostava muito de passear perto de sua aldeia, ver o campo, ouvir os passarinhos e sentar-se junto à margem do rio.

Certa tarde, já o sol se punha, Ynari ouviu um barulho. Não eram os peixes que saltavam na água, não era o cágado que às vezes the fazia companhia, nem era um passarinho verde. (ONDJAKI, 2010, p.29-30)

O fato de Ynari gostar de passear pelos campos, apreciar a paisagem ao seu redor e a companhia dos animais expõe uma sensibilidade infantil e um apego à natureza, não demonstrados de maneira tão intensa nas personagens mais velhas. Os adultos, por exemplo, não demonstram tristeza ou remorso algum em caçar os olongos (espécie de antílope africano), enquanto a menina não gosta de vêlos mortos, mesmo sabendo que a caça só acontecia por motivos de sobrevivência, para que as pessoas da aldeia pudessem se alimentar. 
É interessante destacarmos também o modo como Ynari intervém na situação das cinco aldeias em guerra. Para dar a cada aldeia a habilidade de utilizar a palavra que eles não compreendiam, ela precisa desistir de uma de suas tranças, como podemos perceber no seguinte trecho:

Ynari pediu que todos os habitantes da aldeia fizessem uma fila, trouxessem do rio um bocadinho de água na mão, e pusessem essa água na cabaça. A fogueira já estava acesa, já todos tinham posto o seu bocadinho de água na cabaça, quando Ynari disse algumas palavras, e depois ouviu-se a palavra "permuta". Com a catana do mais velho ela cortou uma trança e deitou-a na enorme cabaça.

- Agora vão todos dormir... - pediu Ynari.

No dia seguinte, quando acordaram, ainda saia fumo da cabaça enorme, e em cima dela estava muitos passarinhos de muitas cores a cantar. O mais velho da aldeia desatou dançar alegremente porque podia ouvir os passarinhos. (ONDJAKI, 2010, p.29-30)

A menina repete esse processo nas aldeias que visita até que não lhe reste nenhuma trança. Sobre o simbolismo que envolve as tranças, compreendemos que

Os cabelos que formam a trança são, como a barba, uma prova de e um meio de forma viril e vital. Além desse símbolo, a trança também significa uma ligação 
provável entre este mundo e o Além dos defuntos, um enlace íntimo de relações, correntes de influências misturadas, a interdependência dos seres. (CHEVALIER; GHEERBRANT, 2012, p.895 - grifo dos autores)

Inferimos, a partir disso, que as tranças de Ynari carregam consigo a própria essência infantil da menina. Elas simbolizam a pureza, simplicidade e inocência, típicas das crianças, assim como sua visão de mundo. Ao abrir mão de suas tranças, a protagonista transfere para as aldeias essas características, assim como o seu modo de ver o mundo. Ao adquirir as habilidades de ouvir, ver, falar, cheirar e sentir sabores, os aldeões também aprendem que precisam viver em harmonia com as outras aldeias. Dessa forma, a criança é reconhecida como sendo essencial para a manutenção dessa sociedade. Percebemos que, em Ynari: a menina das cinco tranças, a criança serve de modelo para o adulto. Os mais velhos valorizam a infância e nela se espelham para aprenderem a viver em paz.

\section{CONSIDERAÇÕES FINAIS}

As noções de criança e de infância são constructos sociais e históricos. As concepções que ora destacamos derivam de uma abordagem eurocêntrica. Entendemos que abordar a Literatura Africana lusófona pelo viés euro-ocidental pode ser 
algo arriscado, no entanto, ao pesquisarmos sobre as noções africanas de infância, percebemos que "os estudos relativos às crianças moçambicanas resultam escassos e difíceis de se encontrar". (COLONNA, 2009, p.6). Entendemos que essa afirmação enunciada pela pesquisadora Elena Colonna não se aplica apenas às crianças moçambicanas, mas também às angolanas e às africanas como um todo.

Além disso, para Colonna (2009), a maioria das pesquisas sobre a infância na África é focada em crianças carentes e que vivem em situações difíceis. Isso acaba obscurecendo outros aspectos que também são importantes e às vezes até mais comuns entre essas crianças. Aos poucos elas têm ganhado visibilidade nas produções científicas, mas a conquista desse espaço ainda acontece de maneira gradual e com dificuldade.

Em Ynari: a menina das cinco tranças, o olhar infantil e a sua compreensão de mundo perpassam toda a narrativa. Percebemos que há a valorização da criança e de seus pensamentos. Compreendemos também que, nessa obra, o infante representa um ideal de promessa que os adultos buscam alcançar, ao viver em harmonia com a natureza e com outros seres humanos, ao ser curioso e ao encarar a vida com simplicidade, encantando-se com todas as descobertas e sendo dotado de uma pureza praticamente desprovida nos mais velhos. Por conta disso, o infante é tido 
como alguém importante, igual ao adulto, que busca, muitas vezes, se espelhar na criança. Portanto, a opinião infantil é sensivelmente valorizada nessa sociedade, tanto que Ynari se configura a pessoa mais adequada a inutilizar a palavra "guerra" e a ensinar aos adultos o emprego primoroso da palavra "paz".

\section{REFERÊNCIAS}

BARBOSA, Analedy Amorim; MAGALHÃES, Maria das Graças S. Dias (2008). "A concepção de infância na visão de Philippe Ariès e sua relação com as políticas públicas para a infância". Examãpaku. Boa Vista, 1(1). In http:// revista.ufrr.br/examapaku/article/view/1456 Acesso em 19.Ago.2016.

CHEVAlIER, Jean; GHEERBRANT, Alain (2012). Dicionário de Símbolos: (mitos, sonhos, costumes, gestos, formas, figuras, cores, números). Rio de Janeiro: José Olympio.

COLLONA, Elena (2008). "O lugar das crianças nos estudos africanos: reflexões a partir de uma investigação com crianças em Moçambique". Poiésis: Revista do Programa de Pós-Graduação em Educação. Tubarão, 1(1). In http://revista.ufrr.br/examapaku/article/view/1456/1050 Acesso em 19.Ago.2016.

COUTINHO, Fernanda (2012). Imagens da infância em Graciliano Ramos e Antoine de Saint-Exupéry. Fortaleza: Banco do Nordeste do Brasil.

FONSECA, Maria Nazareth Soares; MOREIRA, Terezinha Taborda (2007). "Panorama das literaturas africanas de língua portuguesa". Cadernos Cespuc de Pesquisa PUC-Minas. Belo Horizonte, 16, 13-69.

MACEDO, Tânia (2009). "A presença da literatura brasileira na formação dos sistemas literários dos países africanos de língua portuguesa". Revista Crioula. São Paulo, 5. In http://www.revistas.usp.br/crioula/article/ view/54930 Acesso em 11.Ago.2016.

MATA, Inocência (2009). “Inocência Mata: a essência dos caminhos que 
se entrecruzam". Rio de Janeiro. Entrevista concedida à Revista Crioula. In http://www.revistas.usp.br/crioula/article/viewFile/54948/58596 Acesso em 11.Ago.2016.

(2000). “O pós-colonial nas literaturas africanas de língua portuguesa. Congresso Internacional da ALADAA (Associação LatinoAmericana de estudos de Ásia e África)". Rio de Janeiro, Anais. In bibliotecavirtual.clacso.org.ar/ar/libros/aladaa/mata.rtf Acesso em 11.Ago.2016.

ONDJAKI (2010). Ynari: a menina das cinco tranças. São Paulo: Companhia das Letrinhas.

SÁ, Paula Fabrisia Fontinele de; CARVALHO, Diógenes Buenos Aires de (2014). "Retratos de bruxa: as mães-malvadas em Charles Perrault". In: MENDES, Algemira de Mâcedo; CARVALHO, Diógenes Buenos Aires de. (Orgs.). Literatura e gênero: relações de poder, gênero e representações literárias. Teresina: EDUFPI.

Márcia Manir Miguel Feitosa é doutora em Literatura Portuguesa pela USP e Pós-Doutora em Estudos Comparatistas pela ULISBOA. Prof.a Associada IV da UFMA - Campus Bacanga. Docente permanente do Programa de Mestrado Interdisciplinar em Cultura e Sociedade e do Programa de Mestrado em Letras, ambos da UFMA. Autora do livro Fernando Pessoa e Omar Khayyam: o Ruba'iyat na poesia portuguesa do século XX (1998) e organizadora, juntamente com a Prof.a Dr.a Ida Alves, da UFF, do livro Literatura e paisagem: perspectivas e diálogos (2010). Líder do Grupo de Pesquisa em Língua, Discurso e Literatura e do Grupo de Estudos de Paisagem em Literatura (GEPLIT). Co-líder do Grupo de Pesquisa em Estudos da Paisagem nas Literaturas de Língua Portuguesa. Email: marciamanir@hotmail.com.

Vanessa Soeiro Carneiro é mestranda pelo Programa de Pós-Graduação em Letras da UFMA - Campus Bacanga. Membro do Grupo de Estudos de Paisagem em Literatura - GEPLIT. E-mail: vanessasc15@hotmail.com. 